\title{
Aminoglykosider bør fortsatt brukes i empirisk sepsisbehandling
}

\begin{abstract}
Aminoglykosider er potente antibiotika som er spesielt godt egnet til bruk ved alvorlige infeksjoner. I kombinasjon med et celleveggsantibiotikum har det fortsatt en viktig plass i empirisk behandling av sepsis i Norge, til tross for $\emptyset$ kende resistensutvikling.
\end{abstract}

Escherichia coli og Klebsiella pneumoniae utgjør rundt en tredel av funnene i blodkulturer i Norge, og empirisk sepsisbehandling må dekke disse mikrobene. Siden 2003 har vi sett en foruroligende stigning i gentamicinresistens, og i 2011 var henholdsvis $4,4 \%$ og 3,9\% av E. coli og Klebsiella spp. fra blodkultur resistente mot gentamicin (1). Resistens mot aminoglykosider i E. coli og $K$. pneumoniae skyldes i all hovedsak tilstedeværelse av enzymer som modifiserer og inaktiverer aminoglykosidet (2). Det hyppigst forekommende resistensenzymet i Norge (AAC(3)-II) gir resistens mot både gentamicin og tobramycin $(3,4)$. 16SrRNAmetylaser, som koder for høygradig og bredspektret aminoglykosidresistens, er foreløpig sjelden her i landet, men tilfeller har vært beskrevet $(4,5)$.
Aminoglykosidresistens kodes av gener som finnes på mobile genetiske elementer. Dette betyr at resistensgenene forholdsvis

\section{«Aminoglykosidbruken har de siste ti år vært stabil og lav, mens resistensen har økt»}

lett kan overføres mellom bakterier, også mellom spesies. De aktuelle genene er ofte samlokalisert med gener som koder for
Ikke-følsomme isolater (\%)

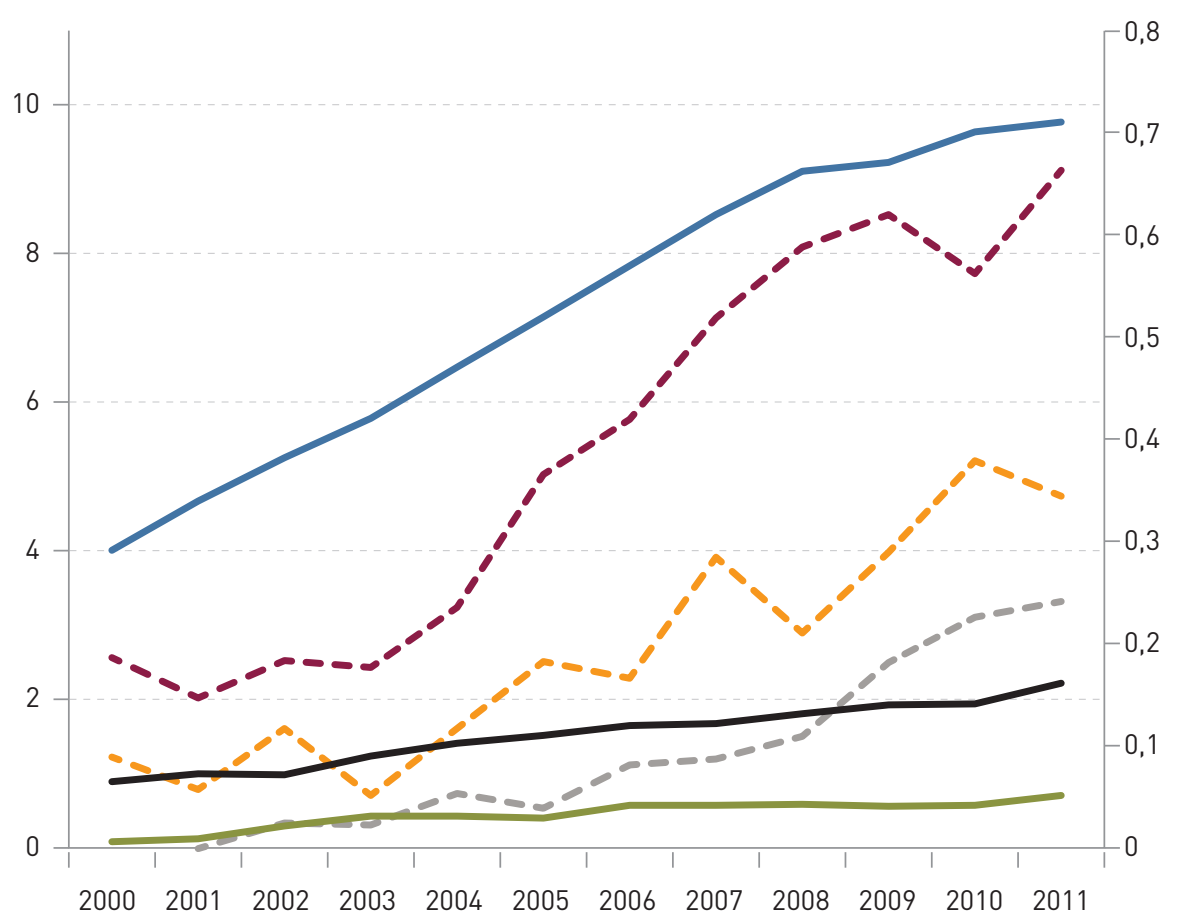

Gentamicin I/R

Ciprofloksacin I/R

ESBL

Forbruk av gentamicin

Forbruk av ciprofloksacin

Forbruk av tredjegenerasjons kefalosporiner

Figur 1 Forekomst av nedsatt følsomhet og resistens (intermediær/resistent, I/R) av gentamicin, ciprofloksa cin og tredjegenerasjons kefalosporiner/ekstendert spektrum-betalaktamaseproduksjon (EBSL) hos E. coli i blodkultur sammen med forbruket av gentamicin, tredjegenerasjons kefalosporiner (cefotaksim, ceftazidim og ceftriakson) og ciprofloksacin for årene 2000-11. Tall fra NORM/NORM-VET 2011 (1) resistens mot andre antibiotikaklasser som betalaktamantibiotika, fluorokinoloner, makrolider, tetrasykliner med flere. For eksempel er opptil $40 \%$ av ekstendert spektrum-betalaktamaseproduserende (ESBL) E. coli- og K. pneumoniae-stammene resistente mot gentamicin $(3,4)$.

Vanligvis er det en sammenheng mellom øt bruk av et antibiotikum og utviklingen av resistens. Dette er godt illustrert ved bruk av ciprofloksacin i Norge (1). En slik klar sammenheng ses ikke hos aminoglykosider. Aminoglykosidbruken har de siste ti år vært stabil og lav, mens resistensen har økt. Det er derfor nærliggende å tenke seg at utviklingen kan skyldes koseleksjon som følge av økt bruk av kinoloner (ciprofloksacin) og tredjegenerasjons kefalosporiner (fig 1).

Trass i økende forekomst av resistens mot gentamicin og tobramycin var over $99 \%$ av E. coli- og Klebsiella spp.-isolater her i landet følsomme for aminoglykosidet amikacin i 2009 (4). Amikacin har tilsvarende virknings- og bivirkningsprofil som gentamicin og tobramycin. Det er ikke markedsført i Norge, og bruken har i hovedsak vært forbeholdt infeksjoner med mykobakterier, der dette aminoglykosidet har en noe bedre effekt. I land med mer utstrakt bruk av amikacin er forekomsten av amikacinresistens høyere. Samtidig er det på grunn av sin molekylære struktur mer robust enn andre aminoglykosider mot resistensutvikling $(6,7)$ og kan være et alternativ når man mistenker spesielle resistensmekanismer.

Gentamicin i kombinasjon med et penicillin har lenge vært anbefalt empirisk behandling ved sepsis i Norge, og denne behandlingsanbefalingen opprettholdes i de nye retningslinjene (8). Det foreligger få studier som underbygger dette regimet, og våre terapivalg er basert på nasjonal behandlingstradisjon og resistensmønster (9). Imidlertid foreligger det flere norske kliniske studier med pasienter med nøytropen feber som viser at kombinasjonsregimet med penicillin og aminoglykosid gir gode kliniske resultater (10-12). Da det trolig også bidrar til å holde resistensnivået her i landet lavt, er dette kombinasjonsregimet fortsatt anbefalt som empirisk behandling ved nøytropen feber (13).

Kombinasjonsregimet med gentamicin og et penicillin bør derfor opprettholdes av to årsaker: 
- Regimet er fortsatt meget godt for alvorlig sepsis forårsaket av grampositive og gramnegative bakterier, selv om det må revurderes dersom gramnegative bakterier med spesielle resistensmekanismer mistenkes

- Alternative empiriske sepsisregimer med ciprofloksacin eller mer bredspektrede antibiotika som kefalosporiner og karbapenemer ville medføre fare for raskere resistensutvikling

Paul Christoffer Lindemann

paul.lindemann@gades.uib.no

Bjørg C. Haldorsen

Ingrid Smith

Haakon Sjursen

Haima Mylvaganam

Paul Christoffer Lindemann (f. 1976) er lege i spesialisering i medisinsk mikrobiologi og stipendiat ved Klinisk institutt 2, Medisinskodontologisk fakultet, Universitetet i Bergen. Doktorgradoppgaven omhandler aminoglykosidresistens i E. coli.

Forfatter har fylt ut ICMJE-skjemaet og oppgir ingen interessekonflikter.

Bjørg C. Haldorsen (f. 1962) er m.sc. og spesialbioingeniør ved Kompetansetjenesten for påvisning av antibiotikaresistens (K-res), Avdeling for mikrobiologi og smittevern, Universitetssykehuset Nord-Norge.

Forfatter har fylt ut ICMJE-skjemaet og oppgir ingen interessekonflikter.

Ingrid Smith (f. 1964) er spesialist i indremedisin og infeksjonssykdommer, overlege ved Nasjonalt kompetansesenter for antibiotika- bruk i spesialisthelsetjenesten, Forskningsog utviklingsavdelingen, Helse Bergen HF og førsteamanuensis ved Klinisk institutt 2, Medisinsk-odontologisk fakultet, Universitetet i Bergen.

Forfatter har fylt ut ICMJE-skjemaet og oppgir ingen interessekonflikter.

Haakon Sjursen (f. 1947) er spesialist i indremedisin og infeksjonssykdommer, overlege ved Infeksjonsseksjonen, Medisinsk avdeling, Haukeland universitetssykehus og professor ved Klinisk institutt 2, Medisinsk-odontologisk fakultet, Universitetet i Bergen.

Forfatter har fylt ut ICMJE-skjemaet og oppgir ingen interessekonflikter.

Haima Mylvaganam (f. 1950), er spesialist i medisinsk mikrobiologi og overlege ved Haukeland universitetssykehus.

Forfatter har fylt ut ICMJE-skjemaet og oppgir ingen interessekonflikter.

\section{Litteratur}

1. NORM/NORM-VET 2011. Usage of antimicrobial agents and occurrence of antimicrobial resistance in Norway. Troms $\varnothing /$ Oslo 2012. www.antibiotikaresistens.no (3.5.2013).

2. Ramirez MS, Tolmasky ME. Aminoglycoside modifying enzymes. Drug Resist Updat 2010: 13: $151-71$.

3. Lindemann PC, Risberg K, Wiker HG et al. Aminoglycoside resistance in clinical Escherichia coli and Klebsiella pneumoniae isolates from Western Norway. APMIS 2012; 120: 495-502.

4. Haldorsen B. Aminoglycoside resistance in clinical gram-negative isolates from Norway. Mastergradsoppgave. Troms $\varnothing$ : Universitetet i Troms $\varnothing$, 2011.

5. Samuelsen O, Thilesen CM, Heggelund L et al. Identification of NDM-1-producing Enterobacteriaceae in Norway. J Antimicrob Chemother 2011; 66: $670-2$.
6. Lambert T. Aminoglycosides and gram-negative bacteria. I: Courvalin P, LeClerq R, Rice L, red. Antibiogram. 3. utg. Washington D.C.: American Society for Microbiology, 2010.

7. Kucers A. Amikacin. I: Kucers A, Crowe SM, Grayson ML et al, red. The use of antibiotics: a clinica review of antibacterial, antifungal and antiviral drugs. 5. utg. Oxford: Butterworth-Heinemann, 1997: $504-6$

8. Nasjonal faglig retningslinje for antibiotikabruk i sykehus. http://helsedirektoratet.no/ kvalitet-planlegging/nasjonale-retningslinjer/ under-arbeid/Sider/nasjonal-faglig-retningslinjefor-antibiotikabruk-i-sykehus.aspx (3.5.2013).

9. Berild D, Haug JB. Fornuftig bruk av antibiotika i sykehus. Tidsskr Nor Legeforen 2008; 128: 2335-9.

10. Sigurdardottir K, Digranes A, Harthug S et al. A multi-centre prospective study of febrile neutropenia in Norway: microbiological findings and antimicrobial susceptibility. Scand J Infect Dis 2005; 37: $455-64$.

11. Tangen JM, Berentsen S, Dahl IM et al. Empirisk antibiotikabehandling hos pasienter med akutt myelogen leukemi. Tidsskr Nor Lægeforen 1999; 119: $35-8$.

12. Torfoss D, Høiby EA, Holte $\mathrm{H}$ et al. Penicillin og aminoglykosid ved febril nøytropeni. Tidsskr Nor Legeforen 2008; 128: 2738-40.

13. Torfoss D, Høiby EA, Holte $\mathrm{H}$ et al. The Norwegian experience with penicillin $\mathrm{G}$ plus an aminoglycoside as initial empiric therapy in febrile neutropenia; a review. Acta Oncol 2012: 51: 433-40.

Mottatt 15.2. 2013, første revisjon innsendt 3.3. 2013, godkjent 25.3. 2013. Medisinsk redaktør Kristin Viste.

Publisert først på nett 